MaReK WoŁodźKO

Badacz niezależny

\title{
Wojna i pokój w społeczeństwie Bora w Amazonii peruwiańskiej ${ }^{1}$
}

W aktualnej debacie antropologicznej, dotyczącej przemocy i wojny w Amazonii, wyróżnia się dwa podejścia. Pierwsze z nich akcentuje współżycie, miłość, hojność i wzajemną troskę jako centralne kategorie i postawy w tubylczych koncepcjach zachowań społecznych (np. Overing, Passes 2002; Santos Granero 1991). Drugie podejście uprzywilejowuje wrogość, przemoc, kanibalizm, wojnę i drapieżnictwo jako aspekt szczególnie ważny w relacjach społecznych (np. Viveiros de Castro 1992). Przedstawiciele pierwszego podejścia zarzucają „szkole przemocy”, że skupianie się tylko na wskazanych aspektach relacji etnicznych nie pozwala do końca zrozumieć indiańskiego mechanizmu uspołeczniania, ponieważ Inni są charakteryzowani głównie przez swoją wrogość i konfliktowość. Z kolei „szkoła przemocy” zarzuca „szkole miłości”, że traktuje społeczności tubylcze w kategoriach szlachetnego dzikiego, co także jest forsowaniem jednego punktu widzenia. Według Robina Wrighta (2012) natomiast obie perspektywy wyrażają dialektykę „wewnętrznej harmonii i zewnętrznej przemocy", wypracowaną przez ludy indiańskie w procesie historycznych przemian.

Prowadząc badania etnograficzne wśród Bora w Amazonii peruwiańskiej, miałem okazję obserwowania i doświadczania różnych relacji społecznych i więzi istniejących między nimi. W pierwszych kontaktach - oficjalnych, werbalnych i normatywnych deklaracjach - Bora prezentowali się jako ludzie etyczni, towarzyscy, dowcipni, bezkonfliktowi i otwarci, o wręcz wyidealizowanej etyce życia społecznego. Jednak z czasem, gdy żyłem pośród nich coraz dłużej i stawałem

\footnotetext{
${ }^{1}$ Podstawę tego tekstu stanowią moje doświadczenia terenowe zdobyte wśród Bora w latach
} 2009-2014 oraz w 2017 r. 
się dla nich coraz bardziej przezroczysty, Bora ujawniali niejako swą drugą twarz, która była konfliktowa, nietolerancyjna, drapieżna, oskarżająca wyłącznie innych o zło tego świata. W niniejszym szkicu interesuje mnie zjawisko konfliktu w społeczeństwie Bora oraz kulturowe formy, jakimi Bora dysponują w celu jego neutralizowania.

Bora są indiańskim ludem mieszkającym w Amazonii peruwiańskiej, w dorzeczu rzeki Ampiyacu. Aktualnie ich liczba oscyluje wokół tysiąca. Wcześniej zamieszkiwali oni obszar Amazonii kolumbijskiej, pomiędzy rzekami Igaraparaná i Caquetá, jednak w wyniku intensywnych wpływów świata zachodniego $\mathrm{w}$ tym regionie, $\mathrm{w}$ okresie boomu kauczukowego na przełomie XIX i XX w. i wymuszonych migracji $w$ połowie lat 30 . XX w., Bora rozprzestrzenili się na inne obszary Peru (rzeki Ampiyacu, Zumun i Momon), Kolumbii i Peru (rzeka Putumayo) oraz Brazylii (rzeka Solimões, między dopływami Tefé i Caiçara, oraz rzeka Içá). Ocenia się, że łączna liczba Bora na wszystkich tych obszarach wynosi ok. 2 tys. Aktualnie ich kultura mocno upodobniła się do kultury metyskich mieszkańców Amazonii peruwiańskiej, kolumbijskiej i brazylijskiej. Na co dzień trudno odróżnić jednych od drugich - Bora noszą ubrania typu metyskiego, $\mathrm{w}$ domach mają $\mathrm{tv}$ i video, są wyznawcami różnych odmian protestantyzmu lub synkretycznego katolicyzmu, wykonują prace typowe dla amazońskich społeczności chłopskich. Także Metysi tego regionu upodobnili się w wielu aspektach do Indian: żują kokę, leczą się u indiańskich uzdrowicieli (curanderos), na lokalne wybory miss piękności ubierają sfolkloryzowane stroje Bora. Razem obie grupy tworzą tzw. sociedad bosquesina - „,społeczeństwo leśne” (Gasché 2007). Wydaje się, że przed całkowitą akulturacją uchroniło Bora ich rozbudowane życie obrzędowe. Najprawdopodobniej to święta i organizujące je osoby, które kroczą "drogą ceremonialną", stały się najmocniejszym spoiwem kulturowym, łączącym w całość praktyki materialne i symboliczne Bora. Są one tak silne i żywotne, że dziś współistnieją ze zjawiskami z kręgu kultury popularnej, działalnością misyjną i edukacją instytucjonalną.

Kulturowo i społecznie Bora należą do areału kulturowego zwanego „ludźmi centrum świata" (w języku bora: pi̇ineé miamúaa, w języku hiszpańskim: gente del centro), który składa się z Huitoto, Bora, Ocaina, Muinane, Nonuya, Andoke i Resigaro - grup etnicznych mówiących odmiennymi językami lub wariantami dialektalnymi tych języków, ale mających takie same praktyki kulturowe ${ }^{2}$. Pomiędzy niektórym grupami etnicznymi tego areału można zaobserwować

\footnotetext{
${ }^{2}$ Na językowy obraz gente del centro składają się: język bora i miraña - w zasadzie dwa dialekty języka bora, język muinane należący do rodziny językowej bora, język ocaina, nonuya - dwa języki należące do rodziny huitoto, ale odmienne względem siebie, język huitoto ze swoimi dialektami mika, bue, minika i nipode, język resigaro z arawackiej rodziny językowej z licznymi zapożyczeniami z języka bora oraz język andoke będący językiem niesklasyfikowanym (Gasché 2009).
} 
„naturalną” wrogość w kontaktach personalnych (np. pomiędzy Bora i Huitoto ${ }^{3}$ ) lub „naturalną” bliskość (np. pomiędzy Bora i Ocaina ${ }^{4}$ ). Jednak najbardziej znamienny wydaje się fakt występowania konfliktów lub zażyłości wśród samych Bora. Ich system pokrewieństwa, tak jak $\mathrm{u}$ innych społeczności gente del centro, opiera się na systemie grup pochodzeniowych (lineażach), których nazwy wywodzą się ze świata roślinnego, zwierzęcego lub odnoszą się do obiektów kulturowych. Grupy te są patrylokalne i egzogamiczne, preferują związki matrymonialne z partnerami spoza macierzystego lineażu. Uważa się, że związki małżeńskie pomiędzy odległymi terytorialnie grupami pochodzeniowymi miały spajać rozrzucone na dużym terytorium maloca (wielkie domy wspólnotowe), które były centrum życia rodzinnego poszczególnych lineaży (Gasché 2009). Chociaż obecnie w obszarze rzeki Ampiyacu te reguły nie są tak rygorystycznie przestrzegane i, jak czasem mówią młodzi Bora: „mamy wolny wybór, z kim chcemy zawrzeć małżeństwo", to w dalszym ciągu wzajemna pomoc czy udział w świętach w odległych osadach w dużym stopniu są wyznaczane przez sieć sojuszy małżeńskich i lineażowych.

Wsród Bora oś podziału na „dobrych” i „złych” przebiega właśnie wzdłuż osi lineażowej, skupiającej blisko spokrewnione z sobą rodziny, które tradycyjnie zamieszkiwały odrębne, pojedyncze maloca, a obecnie tworzą sektory w dużych, stałych osadach złożonych z domów poszczególnych rodzin, ulokowanych względnie blisko siebie. "Dobrzy” to własna grupa pochodzeniowa, „źli" to inne grupy pochodzeniowe, żyjące gdzie indziej - w innym sektorze czy w innej osadzie. Zwraca uwagę fakt zaczerpnięcia z języka hiszpańskiego terminologii określającej inne grupy pochodzeniowe - mówi się o nich często otro tribu (inne plemię), podkreślając wage różnic pomiędzy lineażami. Cechowanie odrębności między nimi wydaje się zrozumiałe, ponieważ, np. w sferze obrzędowości, prawo do wykonywania określonego święta i umiejętność jego prawidłowego wykonania (cargo ceremonial) nabywa się niejako „cieleśnie” przez zstepność (z ojca na najstarszego syna). To więź krwi i fizykalne dzielenie przestrzeni społeczno-kulturowej definiują podobną tożsamość osób z tej samej grupy pochodzeniowej.

Bora, podkreślając wagę rodzinnej zażyłości, mówią, że opieka i moralne wychowanie dzieci to podstawa. A moralne wychowanie to dobre i pozytywne relacje z innymi ludźmi. Stąd też w codziennym życiu rzadko pojawia się przemoc słowna, nie mówiąc już o przemocy fizycznej. Osoba zabiera głos dopiero, gdy jej przedmówca skończy się wypowiadać. Etyka dnia codziennego dotyczy współmierności i umiarkowania, postawy wyrozumiałości dla drugiego człowieka, a jej podstawę stanowi rozmowa, komunikowanie swoich potrzeb oraz słuchanie innych. Nawet w skrajnych przypadkach, np. kilkudniowego pijaństwa jednego z członków rodziny, widać zrozumienie krewnych dla „ułomnej natury” pijanego,

\footnotetext{
${ }^{3}$ Czasem, gdy ktoś w towarzystwie głośno „puszcza wiatry”, mówi się: Murui sale („,wychodzi Murui"). Murui to synonimiczna nazwa na Huitoto.

${ }^{4}$ Bora i Ocaina zawierają między sobą związki matrymonialne.
} 
którzy upatrują w jego stanie rodzaju przejściowej choroby ${ }^{5}$. Choć Bora starają się publicznie nie wyrażać negatywnych opinii na temat drugiej osoby, to jednak prywatnie, w kręgu rodzinnym, nie mają z tym problemu. Przypisują wtedy osobom spoza własnego lineażu, zwłaszcza tym mieszkającym daleko, w górze rzeki czy w mieście, różnego rodzaju działania negatywne, charakteryzujące „złych ludzi”. Oskarżają ich o złodziejstwo, powodowanie chorób, nieuczciwość czy bycie nieprawdziwym Bora. Między krewnymi sposobem zawoalowanej krytyki są żarty i przekomarzania. Bora często mówią o sobie, że są żartownisiami. Podczas każdego spotkania towarzyskiego opisują śmieszne sytuacje dotyczące ich samych i innych - w opowieściach tych ukryty jest przytyk ${ }^{6}$. Kulturowym wyrazem tego pokojowego życia w konflikcie są święta, w czasie których goście (nie-krewni, osoby spoza lineażu) mogą publicznie wyśpiewać wady i złe zachowania goszczących ich gospodarzy.

W języku bora nie ma jednego słowa określającego jednoznacznie wojnę. Określa się ją terminem wieloznacznym lub synonimami odnoszącymi się do stanu emocjonalnego lub działania, np. úmeco (złość, gniew, oburzenie, wojna), ámejcátsi (pobudzenie, wojna, działanie) czy áñujcátsi (działanie), a słowo wojownik istnieje w złożeniach tych słów ze słowem múnáajpi (ludzki, rodak), np. úmeco-múnáajpi (Thiesen W., Thiesen E. 1998). W literaturze przedmiotu możemy znaleźć szczątkowe informacje na temat przemocy fizycznej i walk, jakie Bora prowadzili pomiędzy sobą lub innymi ludami gente del centro. Na przykład para muzykologów argentyńskich, prowadząca badania muzykologiczne wśród Bora w Brillo Nuevo w latach 80. XX w., wspomina, że dawniej, w czasie walk Bora okrywali się wyprawionymi, twardymi skórami pekari, które chroniły ich przed włóczniami wroga (Novati 1984). Z okresu boomu kauczukowego pochodzi przekaz José Enrique Miraña o powstaniu i walce zbrojnej przeciwko caucheros w Kolumbii na przełomie XIX i XX w., na macierzystym obszarze zamieszkiwania genete del centro w dorzeczu rzeki Cahuinari (Miraña, Franco 2009). Według Jorge Gasché (2009) po przybyciu Bora, Huitoto i Ocaina w dorzecze górnego Ampiyacu pozostawali oni w konflikcie z zamieszkującymi te obszary Indianami Yagua, których wyparli w dolny bieg rzeki Ampiyacu. W czasie moich pobytów $\mathrm{w}$ terenie tylko raz spotkałem się z informacją o przemocy wśród samych Bora w przeszłości. Opowiadano mi o zmarłym niedawno 90-letnim mężczyźnie, który w przeszłości był zabójcą, mieszkał na uboczu, poza wspólnotą, z kolejnymi

\footnotetext{
${ }^{5}$ Nie zawsze jednak ten moralny porządek uzyskuje się na drodze wyrozumiałych perswazji. Czasami wymusza się go brutalnie, np. strasząc dzieci, że curuinchi wciągnie je pod ziemię lub syrena utopi je w rzece. Curuinchi to rodzaj mrówek budujących swoje gniazda pod ziemią i niszczących podstawy konstrukcji słupowej domów, a sirena to postać półkobiety-półryby występująca w amazońsko-metyskich mitologiach (Castonguay 1990).

${ }^{6}$ Bora lubią nadawać przydomki odnoszące się do przeszłych wydarzeń uznawanych za śmieszne, w których kryje się wskazanie jakiegoś społecznego zdarzenia czy fizycznego faktu. Na przykład w San Carlos (nazwa zmieniona) na jednego z mężczyzn mówiono Aleman (Niemiec), ponieważ w młodości zakochała się w nim kobieta rasy białej - Niemka, zaś na jednego z otyłych metysów mówiono cahuara - od nazwy ryby charakteryzującej się bardzo dużym brzuchem.
} 
żonami, które maltretował lub zabijał. Na uwagę zasługuje przypadek przemocy "spontanicznej”, który chyba najbardziej oddaje przytoczone wcześniej znaczenie słowa „wojna” w języku bora jako złości, gniewu, oburzenia, pobudzenia, działania. W przeszłości, kiedy w czasie święta w pieśniach wyśmiewano kogoś, jak miało to miejsce w przypadku wspólnych świąt Huitoto i Bora, dochodziło do walk. Urażona osoba uderzała kogokolwiek drewnianą pałką i zaczynała się bójka, która kończyła się tańcami i pieśniami.

W mitach Bora występuje dyskurs przemocy przeplatający się z dyskursem życia w dobrobycie, a wszystko to rozgrywa się w obrębie relacji rodzinnych. Dzieci, rodzice, dziadkowie, bliżsi i dalsi krewni to z jednej strony ci, których się stwarza i chroni, a z drugiej strony też ci, którzy są konkurentami, których się zabija. Pokazuje to fragment opowieści/mitu o pochodzeniu święta:

Gwiazdy są ludźmi, tak jak my. Nie wiem, jak dawniej rozmawiali z gwiazdami, (ale) one były ich - dawnych Bora - przyjaciółmi. Dlatego zapraszały ich na święta, żeby tańczyć razem z nimi, a źli ludzie nas zabijali. Ale jak tam iść, wiedzieli tylko nasi przodkowie, ponieważ byli przyjaciółmi (z gwiazdami). I gwiazdy robiły święta, żeby Bora mogli tam chodzić, do nieba. Było pięknie, żuli kokę, lizali ampiri, pili caguanę, jedli słodką jukę, pięknie tańczyli, nie było żadnej walki, wszyscy byli przyjaciółmi. Ale było bardzo daleko i niebezpiecznie chodzić tak. Lepiej było zrobić takie same święto na ziemi Bora. I odkąd Bora nauczyli się robić święta, nie byli już zapraszani, robili je na swojej ziemi, mogąc żyć spokojnie (relacja Cesara Capino, dolny bieg rzeki Ampiyacu, 2017).

W innym miejscu mitu, już wprost, nie w dyskursie opowieści, mówi się o relacjach pomiędzy ojcem i dziećmi:

(Ojciec wysyła swoje dzieci, dwóch synów, po suri i mówi im):

- Musicie pościć cały miesiąc, możecie jeść tylko casave, coca, caguana - to, nic więcej, cały miesiąc. Idźcie teraz w drogę i wytnijcie drzewo, ale nie jedzcie suri.

Poszli na pole i ścięli drzewo pijuayo ${ }^{8}$, które było pełne suri. Pocięli je na kawałki, jak powiedział ojciec. Młodszy brat chciał spróbować, jak smakuje suri, spróbował. Starszy brat powiedział:

- Ojciec nam zabronił. Dlaczego zjadłeś?

- Ojciec nie będzie wiedział - powiedział młodszy brat. Wrócili do domu.

- Co się stało? - zapytał ojciec.

- On spróbował - powiedział starszy brat.

- A, to jego sprawka - odrzekł ojciec. I młodszy brat stał się brzydki, słaby, jadł swoje ciało, i w końcu, gdy zmarł, ojciec wziął go i spalił.

- A mówiłem, nie próbuj - powiedział ojciec.

Spalił go bardzo dobrze. Został tylko starszy syn. Ale spalony syn powstał i był przeciwko swojemu ojcu, bo ojciec go spalił. Ojciec wygonił go pod ziemię, i dlatego żyje tam - jak mówią - diabeł.

\footnotetext{
7 Larwa jednego z gatunków insektów - Rhynchophorus palmarum.

8 Rodzaj palmy - Bactris gasipaes.
} 
Wcześniej przedstawiłem różne rodzaje przemocy i konfliktów, jakie możemy odnotować w doświadczeniu kulturowym Bora. Są one rozłożone w czasie i akcentują rozproszone obszary kultury. W tej części artykułu przyjrzę się współczesnym konfliktom wśród Bora, pokazującym przedmiot, kategorie i wartości będące powodem ich wewnątrzetnicznej konfliktowości. W tym celu przedstawię konfliktowe sytuacje pomiędzy dwoma grupami pochodzeniowymi żyjącymi w jednej osadzie - „obozem” Alicji z lineażu escoba i „obozem” Canto z lineażu panero w San Pablo, znad rzeki Aprami ${ }^{9}$. Ludzie ci mieszkają w bardzo bliskim sąsiedztwie, po przeciwnej stronie drogi, i w zasadzie każdego dnia mają osobiste kontakty. Współpracują jednak tylko z okazji świąt, na co dzień prowadzą niezależne gospodarstwa. Nie odwiedzają się, z wyjątkiem okazjonalnych spotkań dwóch najstarszych mężczyzn. Ich małe dzieci bawią się czasem w domu lub na zewnątrz, przy dezaprobacie rodziców.

Według Alicji największym problemem Bora nie tylko z San Pablo, lecz także z całego regionu rzeki Aprami, jest brak współpracy. Jako przykład podawała przypadek Mendozy, który wiele razy dostawał znaczne kwoty od naukowców, którzy z nim pracowali, lub od organizacji (bliżej niesprecyzowanych przez Alicję) i z nikim się nie dzielił: „On nigdy się nie dzieli” - mówiła Alicja. „I dlatego ludzie nie chcą mu pomagać. Dlatego jego maloca jest w tak zrujnowanym stanie". Jej zdaniem podstawowy konflikt wśród Bora żyjących w San Pablo wynikał z tego, że "obóz” Canto przejmował wszystkie możliwe dotacje i prezenty z zewnątrz, które były przeznaczone dla społeczności całego San Pablo. Na przykład z tytułu bycia curaca (tytuł obrzędowego przywódcy osady) Canto otrzymał od badacza pracującego z Bora worek ryżu i „inne rzeczy”, które zatrzymał dla swojej rodziny. Od municipio (urzędu gminy) otrzymał 200-litrową plastikową beczkę przeznaczoną dla całej społeczności, a która do tej pory jest używana tylko przez jego rodzinę. Eduard z „obozu” Canto otrzymał od municipio piłę motorową przeznaczoną dla comunidad (sam mówił, że wygrał ją w konkursie), ale również nikomu jej nie pożyczał. Tego rodzaju narracje pojawiały się w rozmowach także z innymi członkami „obozu” Alicji. Na przykład Brunon skarżył się, że jego rodzina pomagała Canto w budowie maloca dla turystów, ale została wykluczona z organizowania dla nich pokazów, które mogły przynieść pokaźne dochody. Kiedy wzmiankowany naukowiec zostawił 10 płyt CD z nagraniami z jednego ze świąt Bora w San Pablo, zarzucono rodzinie Canto, że otrzymała od niego karton pienięd zy i nie podzieliła się z innymi. W odpowiedzi pokazano im płyty z nagraniami, mówiąc, że „to są pieniądze, które śpiewają".

W wyjątkowych wypadkach wzajemna niechęć i niesnaski pomiędzy lineażami przejawiają się w konkretnych działaniach fizycznych. Kiedy na początku XXI w. w dorzecze Aprami zaczęły przyjeżdżać zorganizowane grupy turystów, w San Pablo istniała jedna maloca, która należała do obozu Alicji. W celu

\footnotetext{
9 Imiona osób, nazwy osad, lineaży oraz miejsc zostały zmienione, ponieważ dotyczą konkretnych ludzi, faktycznych zachowań i sytuacji.
} 
przyjmowania turystów i organizowania dla nich pokazów tradycyjnych tańców i pieśni Bora wybudowano za pieniądze municipio drugą maloca, która należała do obozu Canto. I to ta druga maloca stała się celem wycieczek. Turyści, idąc do niej, mijali po drodze maloca „obozu” Alicji. Wtedy kilka razy zdarzyło się, że osoby z „obozu” Alicji z maczetami w ręku „kradły” turystów i przekonywały ich, aby przyszyli do ich maloca.

Niechęć do pomocy może zobrazować przypadek przebudowy dachu domu rodziny Canto w marcu i kwietniu 2011 r., który mogłem obserwować. Wielu członków osady wzięło wtedy udział w kilkudniowym wyjeździe w górę rzeki po liście palmy carana, którymi miała być pokryta maloca. W czasie wyjazdu, oprócz zbierania liści, realizowali oni również swoje indywidualne cele, np. łowili ryby, zbierali surowce roślinne i polowali. Po powrocie poświęcili tylko dwa dni na pokrycie dachu strzechą, później stopniowo przestawali pomagać. Sporadycznie pojawiała się jedna osoba, która pomagała gospodarzom przez krótki czas, po czym odchodziła do swoich zajęć. A kto był jednego dnia, nie przychodził już następnego. Nie dziwi więc, że osoby z „obozu” Canto negatywnie oceniały pozostałych członków osady. Na przykład Jorge narzekał, że ludzie są niegodziwi, nie chcą pomagać, myślą wyłącznie o własnym interesie, przychodzą i współpracują tylko wtedy, kiedy mogą osiągnąć zysk.

W tym krzyżowym ogniu wzajemnych oskarżeń o bycie niegodziwym znalazłem się również ja, kiedy odmówiłem jednemu z Bora przekazania bliżej nieokreślonej kwoty na rzecz comunidad, za to, że mieszkałem w domu curaca. Zostałem wówczas oskarżony o bycie złym i skąpym człowiekiem - hombre malo.

Bora ma kilka mechanizmów kulturowych radzenia sobie z konfliktami wewnętrznymi. Przybliżę tutaj pokrótce trzy z nich: zmianę miejsca zamieszkania, rytualne „walki” między kobietami i mężczyznami oraz święta.

Gdy w osadzie istnieje konflikt i dochodzi do wewnętrznego rozłamu, mieszkańcy mogą zmienić miejsce zamieszkania. Przenoszą się wtedy do innych istniejących już osad lub zakładają nowe, do których z biegiem czasu migrują ich krewni i powinowaci. Pozostawione przez nich domy są niszczone, by nie mieli oni miejsca, do którego mogliby wrócić ${ }^{10}$. Osoby, które odchodzą, są pozbawiane w ten sposób swojej fizykalnej przeszłości, a ci którzy zostają, zacierają po nich wszelki ślad, odmawiając im prawa do bycia „prawdziwymi” Bora, ponieważ są umiejscawiani poza tradycyjną przestrzenią i praktykami ${ }^{11}$.

${ }_{10}$ Tłumaczono mi, że tytuł własności ziemskiej posiada wspólnota indiańska (comunidad) i to do niej, a nie do pojedynczych osób lub rodzin, należą dom oraz miejsca upraw.

${ }^{11}$ Konstruowanie nowych tożsamości etnicznych przyczynia się do stabilizowania tej sytuacji. Ci, którzy wyprowadzili się i mieszkają w mieście lub innej osadzie, w opinii tych, którzy zostali, nie są już "prawdziwymi” Bora, bo nie uprawiają ziemi, tylko tworzą artesanía, jedzą ryż zamiast casave, nie żują koki, tylko piją trago (wódka z trzciny cukrowej). Jednak w opinii "emigrantów" ci, którzy zostali, także nie są "prawdziwymi” Bora, ponieważ należą do evengelicos (wyznawców protestantyzmu), nie uczą swoich dzieci mówić w języku bora, urządzają święta dla turystów lub kupują kokę, zamiast ją samodzielnie uprawiać. 
Drugim sposobem radzenia sobie z konfliktami wewnętrznymi są zrytualizowane „walki” między kobietami i mężczyznami (guerras entre mujeres y hombres). Praktyka ta ma utrwaloną zwyczajowo formułę, ale uzgadnianą i realizowaną ad hoc co do miejsca i czasu. Podczas wspólnego biesiadowania kobiety i mężczyźni częstują się wzajemnie bezalkoholowym napojem z owoców palmy pijuayo (chicha de pijuayo). Jednak konsumpcja napoju to tylko spożywcza delicja, swego rodzaju katalizator spotkania, którego komunikacyjną manifestacją jest „produkcja" śmiechu. Kobiety śmieją się z mężczyzn, wytykając im brak różnych umiejętności i niefortunne zachowania z przeszłości i teraźniejszości. Mężczyźni ripostują, wytykając kobietom ich potknięcia towarzyskie, ujmując to zawsze tak, aby w komentarzu spuentować całość humorystycznym określeniem. Nawet jeżeli humorystyka komentarza jest wątpliwa, wszyscy śmieją się żywiołowym śmiechem. W walkach na dowcipy kobiety są zwykle bardziej twórcze i pomysłowe, ich komentarze i riposty są celniejsze i wywołują więcej salw śmiechu; mężczyźni służą raczej jako „chłopcy do bicia” w tej publicznej walce na słowa. Typowe guerras trwają od dwóch do czterech godzin i w końcowej części, gdy zaczyna już brakować napoju, przekształcają się w rozmowy oraz dłuższe narracje jednej z osób, która chce poinformować o czymś, o czym nie wszyscy wiedzą. Jest to doskonała okazja do wyrażenia swojej opinii i publicznego wysłuchania innych. Na ogół bowiem informacja nacechowana brakiem pewności co do jej prawdziwości krąży z domu do domu jako plotka.

Trudno jest jednoznaczne określić, na ile guerras są buforem społecznych konfliktów, ich społecznym wentylem bezpieczeństwa, dzięki któremu wrogość i zazdrość rozpływają się w atmosferze wspólnego biesiadowania, zmiękczane śmiechem i zabawą. Guerras, w których brałem udział, miały miejsce w gronie ludzi mniej lub bardziej spokrewnionych i spowinowaconych z sobą, z niewielkim udziałem osób „obcych”. Stąd może budzić wątpliwość, na ile są one neutralizatorem społecznych konfliktów w ogóle (w odniesieniu do całej osady składającej się z różnych grup pochodzeniowych), a na ile - wprost przeciwnie - wzmacniają tylko konfliktogenność przez systematyzowanie racji jednej ze stron.

Najbardziej spektakularną i sformalizowaną kulturowo strukturą wyrażania negatywnych postaw i emocji - ale również ich neutralizowania - jest trzeci mechanizm radzenia sobie z konfliktami wewnętrznymi, tzn. święto (fiesta $)^{12}$. Jest ono organizowane przez gospodarza (dueño de la fiesta) oraz pomagających mu krewnych i powinowatych. Na święto są zapraszani członkowie innych osad (invitados, tj. zaproszeni), których zwykle jest ok. 150-200. Święto rozpoczyna się w sobotę przed południem, a kończy w niedzielę ok. 5 rano i - z punktu widzenie śpiewanych w nim pieśni - dzieli się na dwie części. W pierwszej, trwającej w przybliżeniu do 10 wieczorem, są śpiewane canciones antiguas (pieśni dawne), a w drugiej, trwającej do 5 rano, wykonuje się canciones criticas (pieśni krytyczne), zwane czasem canciones modernas (pieśni współczesne). Pieśni dawne to te, które

12 Bora znają 14 rodzajów świąt: dorocznych, związanych z etapami życia lub wydarzeniami, ale współcześnie nie wszystkie są praktykowane (Churay 2001). 
są śpiewane niezmiennie „od zawsze”, mówi się w nich o wydarzeniach mitycznych. W pieśniach krytycznych natomiast nawiązuje się do powszechnie znanych wydarzeń współczesnych. W tym miejscu krótko opiszę sytuację zarówno łagodzenia konfliktów, jak i ich intensyfikacji w dwóch typach świąt, w których uczestniczyłem: báhja wáánaja (związanego z budową maloca) oraz méémeba (związanego z transformacją bytów zwierzęcych jedzących owoce palmy pijuayo w ludzi).

Wykonywanie pieśni krytycznych w czasie święta báhja wáánaja to rodzaj zawodów i walki pomiędzy gospodarzami święta i zaproszonymi gośćmi. Ci ostatni w swoich pieśniach starają się jak najbardziej negatywnie ocenić postępowanie i umiejętności gospodarzy, np. dotyczące przygotowania święta, podczas gdy ci pierwsi w tańcu starają się okrzykami lub śmiechem zmylić frazę pieśni. Przykładowo, w jednej z pieśni twierdzono, że nieodpowiednie przygotowanie święta wywołało złość i zemstę „władcy lasu”, co było bezpośrednią przyczyną dwudniowego deszczu, uniemożliwiającego zaproszonym upolowanie odpowiedniej liczby zwierząt na mitayo ${ }^{13}$. W innej pieśni krytykowano gospodarzy święta za to, że są skąpcami, mają mało koki oraz ampiri14, którą nie chcą częstować. Efektem była natychmiastowa reakcja gospodarzy, którzy częstowali tańczących ampiri. W tym celu śpiewano tę pieśń wielokrotnie w ciągu nocy. W jeszcze innej pieśni krytykowano gospodarza za to, że jego zamieszkała w Iquitos córka ma męża Peruwiańczyka. W kolejnej śmiano się z jego innej córki, również poślubionej przez nie-Bora, że nie zna pieśni i nie żuje koki. Wszystkie te pieśni są śpiewane podczas tańca ${ }^{15}$. Gdy pytałem gospodarza o ich treść, twierdził, że to były tylko "takie żarty". Gdy pytałem o to zaproszonych, śmiali się i cieszyli, że tak mocno przygadano gospodarzowi. Być może więc w czasie święta nie dochodzi do pojednania zwaśnionych stron, być może nawet intensyfikuje się wówczas konflikt, a ujęcie go w dyskurs narracji epickiej przedłuża i wzmacnia jego trwanie? W tym kontekście opowiadano mi o córce innego curaca, która długo płakała po święcie, jakie przygotował jej ojciec, ponieważ niepochlebnie wyrażano się o niej w jednej z pieśni. Niemniej żartobliwa, ekscytująca społecznie atmosfera tańców i pieśni jest nastawiona na komunikację werbalną i fizyczne przebywanie z sobą w wyraźnie zdefiniowanych rolach, co pozwala na wyrażenie wprost tego, co się myśli, pod adresem konkretnych osób i reprezentowanej przez nich grupy z innego lineażu. Na pewno też święta dają okazję do określenia norm, które może nie są powszechnie respektowane, ale dąży się do ich przestrzegania. Dają

${ }^{13}$ Mitayo to system świadczeń ceremonialnych dotyczących wymiany ekonomicznej pomiędzy gospodarzami święta i zaproszonymi.

${ }^{14}$ Ampiri to czysta nikotyna otrzymana z liści tytoniu, zmieszana z solą uzyskaną z kory lub liści niektórych gatunków palm (sale del monte).

${ }^{15}$ Na przykład $\mathrm{w}$ jednym z tańców zaproszeni mężczyźni tańczą w kilku rzędach, uderzając rytmicznie kijami marona $\mathrm{w}$ ziemię. Za nimi, z rękoma wspartymi na ich ramionach, tańczą kobiety gospodarzy, starając się okrzykami, śmiechem i potrząsaniem partnerów, zmylić śpiewaną przez nich pieśń lub krok tańca. Jeżeli się to uda, wszyscy entuzjastycznie, głośno śmieją się i krzyczą. 
one również oręż tym, którzy w pieśniach chcą wyrazić swoją dezaprobatę lub zdyskredytować gospodarza, jego umiejętności, wiedzę i siłę obrzędową.

W 2017 r. uczestniczyłem w święcie méémeba. Jest to święto, które uchodzi za trudne do przygotowania i przeprowadzenia ze względu na wagę poprawnie wykonanych pieśni, masek i tańców inscenizujących zachowania zwierząt, ptaków i owadów spożywających w naturze owoce pijuayo. Jeśli święto zostanie dobrze przygotowane przez gospodarza, nie będzie obfitych opadów w porze deszczowej i dzięki temu goście będą mogli upolować satysfakcjonującą ich zwierzynę, którą przyniosą na obrzędową wymianę z gospodarzami. O tym, że święto było odpowiednio zorganizowane, świadczy m.in. to, że nikomu nic złego się nie stało w czasie przygotowań do niego i w jego trakcie, że nie przytrafił się żaden nieszczęśliwy wypadek, fizyczny ani społeczny. Dlatego jest konieczne dokładne i uważne wykonywanie tańców i pieśni, bez żadnych pomyłek i niestaranności. Przykładowo upuszczenie na ziemię grzechotki w czasie tańca spowoduje chorobę lub śmierć ${ }^{16}$. Dlatego méémeba jest uważne za „niebezpieczne święto” i - jak się mówi - „trzeba wiedzieć, jak je zrobić”, a „nie każdy to umie”.

Dzień po zakończeniu méémeba miały miejsce zdarzenia, które sięgnęły zenitu tubylczej aksjologii. W wyniku zawodu miłosnego 16-letni chłopiec popełnił samobójstwo. Była to jego kolejna próba odebrania sobie życia. Rozpacz najbliższej rodziny była olbrzymia, trzeba było ratować matkę chłopca, żeby i ona nie umarła z rozpaczy. Życie w osadzie skupiło się na tym wydarzeniu; w kilku przypadkach zaprzestano polowań, tłumacząc - z jednej strony - że śmierć osoby w osadzie uniemożliwia upolowanie zwierzyny, z drugiej strony - że emocje i myśl o śmierci nie pozwalają skupić się na czymkolwiek innym. Jako że mieszkałem w maloca gospodarza święta, wcześnie rano byłem świadkiem wielkiego poruszenia wśród domowników, ponieważ dowiedzieli się oni, że w nocy kilku młodych mężczyzn chciało przyjść i zabić gospodarza, bowiem obwiniali go o spowodowanie śmierci chłopca. Sam gospodarz i jego żona płakali, gdyż obawiali się o swoje życie. Mnie proszono, abym więcej nie spotykał się z jednym z tych mężczyzn (moim respondentem), uzasadniając to tym, że przecież widzę, „jaki on jest zły". Gospodarz tłumaczył, że jest niewinny. Wyjaśniał, że nie spowodował śmierci (dosłownie: nie zabił go), ponieważ nie umie tego robić, nie zna formuł słownych, które powodują śmierć ${ }^{17}$. W opinii jednych Bora mógł to jednak

\footnotetext{
${ }_{16}$ Tą kwalifikacją odnosi się bezpośrednio do mitu o pochodzeniu tego święta. Mówi się w nim o dwóch braciach, którzy poszli „daleko”, aby dowidzieć się, jak robi się méémeba, jakie tańce i pieśni wykonuje się w czasie święta. Młodszy brat zdobył większą wiedzę. Starszy brat był o to zazdrosny (sam chciał zostać nauczycielem w swojej grupie), dlatego odciął mu głowę. Grzechotka symbolizuje tu uciętą głowę młodszego brata, czyli nieszczęście, utratę życia. Stąd jest tak wyraźne skupienie uwagi w tańcu na tym, by nie upuścić jej na ziemię.

${ }_{17}$ Chodzi tu o funkcję performatywną języka według odpowiedniej koncepcji Johna Austina. Bora uważają, że nie trzeba "formalizować” intencji czynu za pomocą wypowiedzenia słów, wystarczy o tym pomyśleć lub tego zapragnąć. Na przykład oracje, w których myśliwy prosi władcę lasu o zgodę na polowanie, niekoniecznie muszą być wypowiadane, wystarczy je "pomyśleć w głowie". Podobną rolę pełnią sny, np. śnienie krwi danego gatunku zwierzęcia jest gwarancją udanego nań polowania. Wielokrotnie byłem świadkiem wyjścia na polowanie osób, tylko dlatego, że śniły o konkretnym zwierzęciu.
} 
zrobić, ponieważ jest curandero (uzdrowicielem) i leczy, może więc też powodować śmierć. W tym przypadku odwoływano się do jego umiejętności szamańskich. W opinii innych nie zrobił tego, ponieważ z natury jest dobrym człowiekiem i nie robi „czegoś złego”. W tym przypadku podkreślano cechy osobowościowe gospodarza jako człowieka. Dodam, że osoba, która podkreślała jego umiejętności szamańskie, była z innego lineażu niż gospodarz, a osoba, która odnosiła się do jego cech osobowości, należała do tej samej grupy pochodzeniowej. Przywołane wydarzenia zdają się potwierdzać znaczenie, jakie Bora przypisują méémeba jako bardzo niebezpiecznemu świętu, w czasie lub w następstwie którego może wydarzyć się "coś złego".

W szkicu przybliżyłem zjawisko konfliktu pośród Bora z Amazonii peruwiańskiej. Starałem się zarysować różnice pomiędzy relacjami społecznymi wewnątrz grupy pochodzeniowej i pomiędzy takimi grupami. Wskazałem, że relacje we własnej grupie charakteryzuje duża wrażliwość i wzajemna etyka oraz wyrozumiałość dla postępowania członków grupy. Relacje pomiędzy grupami pochodzeniowymi natomiast są opatrzone sankcją negatywną - to innych, spoza własnego lineażu, posądza się o złe intencje, złą wolę i własną niepomyślność. Wskazałem też na wypracowane przez Bora kulturowe formy neutralizacji konfliktów międzygrupowych (opuszczanie osad o intensywnym konflikcie, walki pomiędzy kobietami i mężczyznami oraz święta), których status neutralizujący nie jest do końca jednoznaczny.

Na koniec chcę zwrócić uwagą na jeden z aspektów konfliktowości wśród Bora, tzn. na przedmiot ich sporów, który odnosi się do codziennych praktyk. Wydaje się, że spory Bora są banalne, bo toczą się o banalne sprawy - plastikową beczkę, worek ryżu, źle zaśpiewaną frazę pieśni czy pieniądze, które podobno ktoś otrzymał. Spory te są jednak stawiane na ostrzu noża, a Bora w największych emocjach dążą do udowodnienia swojej racji. Konflikty te pokazują, jak ważne w ich społeczeństwie są wyznawane przez nich wartości: dbania o wspólne dobro, dzielenia się, utrzymywania dobrych relacji z innymi, wzajemna pomoc czy związki małżeńskie w ramach własnej grupy, gwarantujące przekazywanie własnych wzorów kulturowych, o czym komunikuje się publicznie w czasie święta w formie epickiej. W sytuacji gdy obecnie tradycyjne kategorie kulturowe Bora są konfrontowane z treściami i kulturą społeczeństwa narodowego, Bora tracą dotychczas wyraźne i jasne dla nich wektory postępowania i jeszcze bardziej piętnują się wzajemnie w orzekaniu o tym, kto jest „prawdziwym Bora”. Wydaje się, że uzewnętrznianie konfliktów jest pewnego rodzaju wentylem bezpieczeństwa uwalniającym wrogość, która, gdyby była tłumiona, mogłaby przerodzić się w krwawą przemoc (zob. Coser 2009). Stąd wydaje się możliwe, że lęk i agresja wobec swoich-obcych wzrasta, gdy zawodzą dotychczas wyraźnie uchwytne tożsamości siebie samych i swoich bliskich. 


\section{Literatura}

Castonguay, L. (1990). Vocabulario Regional del Oiente Peruano. Iquitos: Centro de Estudios Teologicos de la Amazonia.

Coser, L.A. (2009). Funkcje kofliktu społecznego. Kraków: Nomos.

Churay Flores, V. (2001). Fiestas tradicionales de los boras. Lima: Universidad Nacional Mayor de San Marcos.

Chaumeil, J.-P. (1981). Historia y migraciones de los Yagua de finales del siglo XVII hasta nuestros dias (s. 16-18). Serie Antropologica No. 3. Lima: CAAP.

Echeverri, J.A. (1997). The people of the center of the world. A study in culture, history and orality in the Colombian Amazon. New York: New School for Social Research, Faculty of Political and Social Science.

Gasché, J. (2007). ¿Para qué sirve el concepto de ‘sociedad bosquesina’?. Folia Amazónica, $16(1-2), 81-88$.

Gasché, J. (2009). La sociedad de la "gente del centro". W: F. Seifart et al. (eds.), A multimedia documentation of the languages of the People of the Center. Nimega: DOBES-MPI, www.corpus1.mpi.nl/qfs1/mediaarchive/dobes_data/Center/Info/1.3_Sociedad.pdf. [dostęp: 25.10.2017].

Miraña, J.E., Franco, R., Bora, A.B. (2009). Testimonios y Relatos para la historia de los mirañas y boras del río Cahuinarí (1710-2008). Bogotá: AATI Pani.

Novati, J. (1984). Mekamunaa: estudio etnomusicologico sobre los Bora de la Amazonia Peruana. Buenos Aires: Institutio Nacional de la Musicología "Carlos Vega".

Overing, J., Passes, A. (eds.). (2002). The Anthropology of Love and Anger: the Aesthetics of Conviviality in Native Amazonia. London-New York: Routledge.

Santos Granero, F. (1991). The Power of Love. The Moral Use of Knowledge amongst the Amuesha of Central Peru. London: The Athlone Press.

Thiesen, W., Thiesen, E. (1998). Diccionario bora-castellano, castellano-bora. Lima: Instituto Linguistico de Verano.

Wright, R. (2012). Arawakan Flute Cults of Lowland South America: The Domestication of Predation and the Production of Agentivity. W: J.H. Hill, J.-P. Chaumeil (eds.), Bursts of Breath: New Research on Indigenous Flutes in Lowland South America (s. 325-356). Omaha: University of Nebraska.

Viveiros de Castro, E. (1992). From the Enemy's Point of View: Humanity and Divinity in an Amazonian Sociaty. Chicago: University Chicago Press.

\section{SUMMARY}

War and peace in the Bora community in the Peruvian Amazon

In the article, I discuss the social conflict and violence as well as cultural methods of their neutralization in the culture of Bora Indians from the Peruvian Amazon. The conflict in a small Amazonian community, in which everyone knows each other, is conditioned by the relationships of blood and affinity. The cultural forms of neutralization of the conflict are: migration from places with intense conflict, ceremonial and festive ceremonies. Bora stigmatize each other when their traditional categories of social coexistence - sharing, mutual help, caring for the common good - fail in confrontation with values of the national society.

Keywords: Social conflict, Bora, gente del centro, cultural mechanisms of conflict resolution, méémeba, the Peruvian Amazon. 